\title{
Hydrogen sulfide, potassium phosphite and zinc sulfate as alleviators of drought stress in sunflower plants
}

\author{
Sulfeto de hidrogênio, fosfito de potássio e sulfato de zinco como aliviadores do \\ estresse por seca em plantas de girassol
}

\author{
Gabriel Martins Almeida1 (D), Adinan Alves da Silva1 (D), Priscila Ferreira Batista' (D), \\ Luciana Minervina de Freitas Moura' (iD, Roberto Gomes Vital ${ }^{1}$ (D), Alan Carlos Costa ${ }^{1 *}(\mathbb{D})$
}

'Instituto Federal Goiano/IF Goiano, Campus Rio Verde, Laboratório de Ecofisiologia e Produtividade Vegetal, Rio Verde, GO, Brasi

*Corresponding author: alan.costa@ifgoiano.edu.br

Received in March 18, 2020 and approved in July 17, 2020

\begin{abstract}
Drought is the most harmful environmental factor crop productivity. Some chemicals are used in agriculture to mitigate the damage from this stress on plants. Therefore, we examined whether the spraying of zinc sulfate (ZS), potassium phosphite (KPhi) and the hydrogen sulfide $\left(\mathrm{H}_{2} \mathrm{~S}\right)$ donor sodium hydrosulfide $(\mathrm{NaHS})$ would mitigate the deleterious effects of water deficit on sunflower plants by analyzing physiological and biometric characteristics. The experiment was carried out in a greenhouse using a randomized block design with five replications. The treatments were arranged in a $4 \times 2$ factorial scheme: [Factor A (Alleviators)] - spraying of KPhi $(0.5 \mathrm{~L} \mathrm{ha-1}), \mathrm{ZS}(3.2 \mathrm{~kg} \mathrm{ha-1})$, NaHS (1.2 $\mathrm{g} \mathrm{ha}^{-1}$ ), and water; [Factor B (substrate humidity, SH)] - 100\% (well irrigated) and 30\% (water deficit, WD) of field capacity. Under WD conditions, alleviators led to the maintenance of higher values of water potential $\left(\Psi_{w}\right)$, a lower content of leaf malonaldehyde (MDA), and increased activity of the antioxidant enzyme peroxidase (POX), except for ZS. However, leaf osmotic potential, proline concentration, variables related to gas exchange and chlorophyll $a$ fluorescence, and biometric characteristics differed only according to the $\mathrm{SH}$ factor. The results of $\Psi_{w}$ and MDA for sunflower plants under WD are indicative of the mitigating capacity of ZS, KPhi, and $\mathrm{H}_{2} \mathrm{~S}$. Thus, the spraying of these compounds on sunflower plants mitigates the effects of WD, acting specifically in physiological processes related to antioxidant responses and in the maintenance of water in leaf tissues.
\end{abstract}

Index terms: Photosynthesis; water deficit; malonaldehyde; leaf water potential; mitigating substance.

\begin{abstract}
RESUMO
A seca é o fator ambiental que mais prejudica a produtividade das culturas. Alguns produtos químicos têm sido utilizados na agricultura para mitigar os danos causados por esse estresse nas plantas. Portanto, examinamos se a pulverização dos compostos sulfato de zinco (ZS), fosfito de potássio (FP) e doador de sulfeto de hidrogênio $\left(\mathrm{H}_{2} \mathrm{~S}\right)$ - hidrossulfeto de sódio (NaHS) - mitigam os efeitos deletérios do déficit hídrico em plantas de girassol, analisando características fisiológicas e biométricas. O experimento foi conduzido em casa de vegetação sob delineamento de blocos ao acaso com cinco repetições. Os tratamentos foram arranjados em esquema fatorial $4 \times 2$ : [Fator A (aliviadores)] - pulverização de FP $\left(0.5 \mathrm{~L} \mathrm{ha}^{-1}\right)$, ZS (3.2 kg ha-1), NaHS (1.2 $\left.\mathrm{g} \mathrm{ha}^{-1}\right)$, e água; [Fator B (umidade do substrato, US)] - 100\% (bem irrigado) e 30\% (déficit hídrico, DH) da capacidade de campo. Nas condições de $\mathrm{DH}$, os aliviadores levaram à manutenção de maiores valores de potencial hídrico $\left(\Psi_{\mathrm{w}}\right)$, menor teor de malonaldeído foliar (MDA) e aumento da atividade da enzima antioxidante peroxidase (POX), exceto para ZS. Entretanto, o potencial osmótico foliar, a concentração de prolina, as variáveis relacionadas às trocas gasosas, fluorescência da clorofila $a$ e as características biométricas diferiram apenas em função do fator US. Os resultados de $\Psi_{w}$ e MDA em plantas de girassol sob DH são indicativos da capacidade mitigadora do ZS, FP e $\mathrm{H}_{2} \mathrm{~S}$. Assim, a pulverização desses compostos em plantas de girassol mitiga os efeitos do DH, atuando especificamente em processos fisiológicos relacionados a respostas antioxidantes e na manutenção de água nos tecidos foliares.
\end{abstract}

Termos para indexação: Fotossíntese; déficit hídrico; malonaldeido; potencial hídrico foliar; substância mitigadora.

\section{INTRODUCTION}

The sunflower (Helianthus annuus L.) has great importance in the world economy as one of the most cultivated oilseed crops (Castro; Leite, 2018). Sunflower seeds contain $38 \%$ to $50 \%$ oil, which is widely used in human food and the production of biodiesel (Miladinović et al., 2019). The average productivity of sunflower crops in the worldwide was $1803.9 \mathrm{~kg} / \mathrm{ha}$ in 2019 (FAO, 2019). Many environmental factors contributed to the nonachievement of greater productivity in the sunflower harvest in Brazil, which highlights the increase in the frequency of drought seasons (Soares et al., 2019). Large economic 
losses were reported for Brazilian agribusiness, primarily due to periods of severe drought in the field (Ribeiro et al., 2018). Increases in these abiotic stress events are among the consequences of anthropogenic global warming (Mora et al., 2017; Dai; Zhao; Chen, 2018), which threatened agricultural productivity worldwide.

Plants exposed to water deficit show changes in several physiological and biochemical processes, such as chlorophyll degradation (Zhou et al., 2014), cell osmotic adjustment (Batista et al., 2020), reduction in stomatal opening and carbon dioxide $\left(\mathrm{CO}_{2}\right)$ assimilation (Tariq et al., 2018). The increase in the formation of reactive oxygen species (ROS) in plants exposed to water deficit is also noteworthy (Batista et al., 2018). ROS promote membrane lipid peroxidation and the oxidation of macromolecules, such as nucleic acids and proteins (Rivas et al., 2017; Tariq et al., 2018). Under oxidative stress, higher concentrations of malonaldehyde (MDA) are an indicative of cellular damage, and increases in the activity of antioxidant enzymes act in the plant defense against the stress (Li et al., 2017).

Finding methods to minimize the negative effects of water restriction is essential for maintaining crop productivity. An alternative technique to mitigate the damage of abiotic stresses in plants is the application of different classes of chemical compounds using, via leaf spraying (Dinis et al., 2016; Van Oosten et al., 2017; Kahlaoui et al., 2018; Sabir; Sari, 2019). Among the numerous alleviators researched, zinc sulfate (ZS) potassium phosphite (KPhi), and hydrogen sulfide $\left(\mathrm{H}_{2} \mathrm{~S}\right)$ mitigated stress due to water deficit via maximizing the physiological processes involved in maintaining turgor and increasing antioxidant metabolism (Batista et al., 2020).

The ZS application increases enzyme antioxidant defenses and prevents oxidative stress in plants (Ma et al., 2017). ZS also contributes to higher levels of total chlorophyll, abscisic acid and proline, and well as improves the efficiency of stomatal control (Monjezi; Vazin; Hassanzadehdelouei, 2013; Zafar et al., 2014). Potassium phosphite (KPhi) was initially proposed as a protective fungicide, but studies described its potential as a plant biostimulant, and it induced tolerance to abiotic stresses (Gómez-Merino; Trejo-Téllez, 2015). This effect was verified via the stimulation of antioxidant enzymes, such as superoxide dismutase (SOD), ascorbate peroxidase (APX) and guaiacol peroxidase (POX) (Oyarburo et al., 2015; Machinandiarena et al., 2018).

In addition to foliar fertilizers, cell signaling molecules show several improving effects on plant metabolism, such as the performance of hydrogen sulfide $\left(\mathrm{H}_{2} \mathrm{~S}\right)$ in inducing antioxidant defenses and, improving the photosynthetic capacity and stomatal control of plants in water deficit conditions (García-Mata; Lamattina, 2010; Corpas, 2019). Therefore, the application of the $\mathrm{H}_{2} \mathrm{~S}$ donor NaHS (sodium hydrosulfide) promoted increases in the relative water content and antioxidant defenses in soybean under drought (Batista et al., 2020). Smaller amounts of ROS and MDA were also verified (Zhang et al., 2010). These studies support NaHS as a potential reliever of abiotic stresses in cultivated plants (Singh; Tripathi; Fotopoulos, 2020).

The present study tested the hypothesis that ZS, $\mathrm{KPhi}$ and $\mathrm{H}_{2} \mathrm{~S}$ would improve the tolerance of sunflower to water deficit. This study is the first report on the application of these three compounds to sunflower plants under water deficit conditions. Thus, the objective was to verify whether the foliar spraying of ZS, KPhi and NaHS alleviated the deleterious effects of water deficit on sunflowers and, provided better water and osmotic adjustment, protection against cellular damage, maintenance of $\mathrm{CO}_{2}$ assimilation and plant growth.

\section{MATERIAL AND METHODS}

\section{Plant material and experimental conditions}

The experiment was performed in a pad-cooled greenhouse where the air temperature was programmed not to exceed $27^{\circ} \mathrm{C}$. The greenhouse is located at the Instituto Federal Goiano - Campus Rio Verde, Goiás, Brazil. The sunflower hybrid used in this study was the Sany 66 (Atlântica Sementes ${ }^{\circledR}$ ), with a cycle of approximately 110 days. Sunflower plants were grown in plastic pots containing $5 \mathrm{dm}^{-3}$ of substrate $\left(\right.$ Bioplant ${ }^{\mathbb{R}}$ ), one plant per pot. Each pot was fertilized with $4.6 \mathrm{~g}$ of the formulated fertilizer 10-10-10 (NPK) and 0.32 $\mathrm{g}$ of the formulated FTE $\mathrm{BR} 12(\mathrm{~S}=3.2 \% ; \mathrm{B}=1.8 \% ; \mathrm{Cu}=0.18 \% ; \mathrm{Mn}=2.0 \% ; \mathrm{Mo}$ $=0.1 \% ; \mathrm{Zn}=9.0 \%)$.

\section{Experimental design}

The experimental design was arranged in randomized blocks, with five (5) replicates. It consisted of a $4 \times 2$ factorial design: [Factor A (alleviators and water)] 1) spraying of $0.5 \mathrm{~L} \mathrm{ha}^{-1}$ potassium phosphite (KPhi), 2) $3.2 \mathrm{~kg} \mathrm{ha}^{-1}$ zinc sulfate (ZS), 3) $1.2 \mathrm{~g} \mathrm{ha}^{-1}$ sodium hydrosulfide (NaHS), and 4) water (without product, WP) and [Factor B (Substrate humidity, SH)] 1) 100\% wellwatered control (WW), and 2) $30 \%$ (water deficit, WD) of field capacity (FC). 


\section{Imposition of treatments and analysis}

Thirty-eight days after sowing and at the R1 stage, sunflower plants were sprayed one day before the imposition of the water regimes using a sprayer pressurized by $\mathrm{CO}_{2}$, four-tip bar type XR11002-VP, with a double fan and a spray volume equivalent to $200 \mathrm{~L} \mathrm{ha}^{-1}$ via pressure regulation of 2 bar. The meteorological data at the time of application were $24.8{ }^{\circ} \mathrm{C}$ temperature and $88.3 \%$ relative humidity, as measured using a Kestrel 4000 weather meter (Kestrel Instruments, Nielsen-Kellerman Company). For the imposition of water treatments, the FC of the cultivation substrate was determined using a gravimetric method (Costa et al., 2015). To control substrate moisture during the stress period, each pot was weighed twice daily (11 am and $5 \mathrm{pm}$ ), and the water lost through evapotranspiration was replaced, to maintain the plants as well-watered (WW) or under water deficit (WD) using 100 and $30 \%$ of FC, respectively. Ten days after the imposition of treatments (DAIT), analyses of water relations, gas exchanges, chlorophyll $a$ fluorescence, concentration of chloroplast pigments, content of proline and malonaldehyde, antioxidant enzyme activity and biometric measurements were performed.

\section{Water relations}

Predawn leaf water potential $\left(\Psi_{\mathrm{w}}\right)$ was measured using a Scholander pressure chamber (model 3005-1412, Soilmoisture Equipment Corp.), between 04:00 and 06:00 in the morning. For the evaluation of leaf osmotic potential $\left(\Psi_{\mathrm{S}}\right)$, the cellular exudate was extracted from the leaves and $10 \mu \mathrm{L}$ analyzed using a vapor pressure osmometer (model 5600, VAPRO, Wescor, Logan, Utah, USA) (Pask et al., 2012). Osmotic potential values were obtained using the Van't Hoff's equation: $\Psi_{\mathrm{S}}=-\mathrm{R} \times \mathrm{T} \times \mathrm{Cs}$, where $\mathrm{R}$ is the universal gas constant $\left(0.082051 \mathrm{~atm} \mathrm{~mol}^{-1} \mathrm{~K}^{-1}\right)$, $\mathrm{T}$ is the temperature $\left(\mathrm{T}^{\circ} \mathrm{K}=\mathrm{T}{ }^{\circ} \mathrm{C}+273\right)$, and $\mathrm{Cs}$ the solute concentration $(\mathrm{M})$, usually expressed in atmospheres and converted to $\mathrm{MPa}(0.987 \approx 1 \mathrm{~atm}=0.1 \mathrm{MPa})$.

\section{Gas exchange}

Gas exchanges of the plants were measured using a portable infrared gas analyzer with coupled modulated fluorometer (IRGA, model LI6800xt, Li-Cor, Nebraska, United States), on the latest fully expanded plant leaf. Net photosynthetic rate $\left[A, \mu \mathrm{mol}\left(\mathrm{CO}_{2}\right) \mathrm{m}^{-2} \mathrm{~s}^{-1}\right]$, transpiration rate $\left[E, \operatorname{mmol}\left(\mathrm{H}_{2} \mathrm{O}\right) \mathrm{m}^{-2} \mathrm{~s}^{-1}\right]$, stomatal conductance $\left[g_{\mathrm{s}}\right.$, mol $\left.\left(\mathrm{H}_{2} \mathrm{O}\right) \mathrm{m}^{-2} \mathrm{~s}^{-1}\right]$, and the ratio between internal and external $\mathrm{CO}_{2}$ concentration $\left(C_{\mathrm{i}} / C_{\mathrm{a}}\right)$ were measured under photosynthetically active radiation (PAR) of $1500 \mu \mathrm{mol} \mathrm{m} \mathrm{m}^{-2} \mathrm{~s}^{-1}$ and a block temperature of $25^{\circ} \mathrm{C}$. The instant water use efficiency was obtained by the formula $E U A=[A / E, \mu \mathrm{mol}$ $\left.\left(\mathrm{CO}_{2}\right) \mathrm{mmol}\left(\mathrm{H}_{2} \mathrm{O}\right)^{-1} \mathrm{~m}^{-2} \mathrm{~s}^{-1}\right]$.

\section{Chlorophyll a fluorescence}

The fluorescence variables of chlorophyll $a$ were recorded on the same leaf of photosynthesis using a portable modulated fluorometer coupled to the IRGA (LI6800xt, Li-Cor, Nebraska, United States). The evaluations were performed in the dark-adapted leaves, so that the reaction centers were fully open (primary oxidized receptors) with minimal heat loss. Leaves were initially dark-adapted to estimate the initial fluorescence $\left(\mathrm{F}_{0}\right)$, maximum fluorescence $(\mathrm{Fm})$ and potential quantum yield of photosystem II (PSII) $F_{\mathrm{v}} / F_{\mathrm{M}}=\left[\left(\mathrm{F}_{0}-\mathrm{Fm}\right) /\right.$ Fm] (Genty; Briantais; Baker, 1989). The slow phase variables were obtained after the application of an actinic illumination, followed by a pulse of saturated actinic light for the determination of steady-state fluorescence $(F)$ and maximum fluorescence in a sample adapted to light (Fm'), respectively, allowing to calculate the effective quantum yield of photochemical energy conversion in PSII $\left(\Phi_{\mathrm{II}}\right)$ $\left.=\left(\mathrm{Fm}^{\prime}-\mathrm{F}\right) / \mathrm{Fm}^{\prime}\right]$. The $\Phi_{\mathrm{II}}$ was also used to estimate the apparent electron transport rate, $E T R=\Phi_{\mathrm{II}}$. PAR $\times$ Aleaf $\times 0.5$ (Bilger; Schreiber; Bock, 1995), where PAR is the photon flow $\left(\mu \mathrm{mol} \mathrm{m} \mathrm{m}^{-2} \mathrm{~s}^{-1}\right)$ on the leaves, $A_{\text {leaf }}$ is the amount corresponding to the fraction of incident light that is absorbed by the leaves and 0.5 is the excitation energy fraction directed to the PSII (Laisk; Loreto, 1996). The non-photochemical quenching coefficient (NPQ) was calculated as NPQ $=(\mathrm{Fm}-\mathrm{Fm}$ ' $) / \mathrm{Fm}$ '; and the relative energy excess at the PSII level as $\left(\mathrm{EXC}=\left(F_{\mathrm{V}} / F_{\mathrm{M}}\right)-(\mathrm{Fq}\right.$ '/ Fm') $/\left(F_{\mathrm{v}} / F_{\mathrm{M}}\right)$ (Bilger; Schreiber; Bock, 1995).

\section{Pigment concentration}

Pigment concentration was determined by extraction with dimethylsulfoxide (DMSO) saturated with calcium carbonate $\left(\mathrm{CaCO}_{3}\right)$ according to Castro et al. (2019). Three leaf discs $\left(0.6 \mathrm{~cm}^{2}\right)$ were incubated in $5 \mathrm{~mL}$ of DMSO solution, and the pigments were extracted for $24 \mathrm{~h}$ in a water bath set to $65^{\circ} \mathrm{C}$. The spectrophotometric readings were later obtained at 480.0, 649.1, and 665.1 nm using a UV-VIS spectrophotometer (model Evolution 60S, Thermo Fisher Scientific Inc.). The chlorophyll $a$ $\left(\mathrm{Chl} a=12.19 A_{665}-3.45 A_{649}\right)$, and chlorophyll $b$ (Chl $b$ $\left.=21.99 A_{649}-5.32 A_{665}\right)$ and total carotenoids (Carot $=$ $\left.\left(1000 A_{480}-2.14 \mathrm{C}_{\mathrm{a}}-70.16 \mathrm{C}_{\mathrm{b}}\right) / 220\right)$ concentrations were calculated according to Wellburn (1994) and expressed in micrograms per leaf area. 


\section{Determination of proline content}

For free proline measurement, $200 \mathrm{mg}$ of fresh leaf material was homogenized in $4 \mathrm{~mL}$ of $80 \%$ ethanol according Bates, Waldren and Teare (1973), with some modifications. After centrifugation $(6300 \mathrm{~g}, 10 \mathrm{~min})$, an aliquot of $250 \mu \mathrm{l}$ of filtrate extract was mixed with $2 \mathrm{~mL}$ acid ninhydrin $(1.25 \mathrm{~g}$ ninhydrin, $30 \mathrm{~mL}$ glacial acetic acid, $20 \mathrm{~mL} 6 \mathrm{M}$ orthophosphoric acid in $200 \mathrm{~mL}$ ), $2 \mathrm{~mL}$ of glacial acetic acid and $2.65 \mathrm{~mL}$ of water. The samples were incubated at $90{ }^{\circ} \mathrm{C}$ in a water bath for $35 \mathrm{~min}$ and, after this period, placed on ice to stop the reaction. We added $4 \mathrm{~mL}$ of toluene to the solution, followed by stirring for complete separation of the chromophore-containing toluene to be analysed. The absorbance of the supernatant was measured at $515 \mathrm{~nm}$ in a UV-VIS spectrophotometer (model Evolution 60S, Thermo Fisher Scientific Inc.). The proline concentration was calculated by comparison with a proline standard curve ( 0 to $100 \mu \mathrm{g} \mathrm{mL}^{-1}$ ) and was expressed as $\mu \mathrm{mol} \mathrm{g} \mathrm{FM}^{-1}$.

\section{Determination of malondialdehyde (MDA)}

The content of MDA was evaluated to determine the lipid peroxidation using the method proposed by Heath and Packer (1968). Leaf samples $(0.160 \mathrm{~g})$ were homogenized in $2 \mathrm{~mL} 0.1 \%(\mathrm{w} / \mathrm{v})$ trichloroacetic acid (TCA), and the homogenate was centrifuged at $12000 \mathrm{~g}$ for 15 min at $4{ }^{\circ} \mathrm{C}$. The supernatant $(500 \mu \mathrm{L})$ was mixed with 2 $\mathrm{mL}$ of TBA reagent $(0.5 \%$ [w/v] of TBA in $20 \%$ TCA $)$. The reaction mixture was heated at $90{ }^{\circ} \mathrm{C}$ for $20 \mathrm{~min}$ in a water bath and then quickly cooled in an ice bath and centrifuged at $3000 \mathrm{~g}$ for $4 \mathrm{~min}$. The absorbance of the colored supernatant was monitored at 440, 532 and $600 \mathrm{~nm}$ using a UV-VIS spectrophotometer (Evolution 60S, Thermo Fisher Scientific, Madison, EUA). The concentration of MDA was calculated using the molar extinction coefficient of $155 \mathrm{mM}^{-1} \mathrm{~cm}^{-1}$ according to the following equation: MDA $\left(\mathrm{nmol} \mathrm{mL} \mathrm{m}^{-1}\right)=[(\mathrm{A} 532-\mathrm{A} 600) / 155000] 10^{6}$. The concentration of MDA in leaves was expressed nmol TBA-MDA g ${ }^{-1}$ FW (Heath; Packer, 1968).

\section{Determination of peroxidase activity}

Peroxidase (POX, EC 1.11.1.7) activity was determined by addition of the crude enzyme extract to a reaction mixture containing $25 \mathrm{mM}$ potassium phosphate buffer (pH 6.8), $20 \mathrm{mM}$ pyrogallol and $20 \mathrm{mM}$ hydrogen peroxide (Kar; Mishra, 1976). The reaction was measured at $420 \mathrm{~nm}$ in a UV-VIS spectrophotometer for $1 \mathrm{~min}$ at $25{ }^{\circ} \mathrm{C}$. An extinction coefficient of $2.47 \mathrm{mM}^{-1} \mathrm{~cm}^{-1}$ (Chance; Maehley, 1955) was used to calculate POX activity and was expressed as $\mu \mathrm{mol} \mathrm{min} \mathrm{mg}^{-1}$ of protein. Protein concentration was determined according to Bradford (1976).

\section{Biometry}

The plants were measured to determine the biometric variables: plant height $(\mathrm{H}, \mathrm{cm})$, number of leaves, number of nodes, and stem diameter $(\mathrm{mm})$. Leaves and stem were separated into paper bags and oven dried at $65{ }^{\circ} \mathrm{C}$ for $72 \mathrm{~h}$ to obtain leaf dry matter $(\mathrm{g})$ and stem dry matter $(\mathrm{g})$.

\section{Statistical analysis}

The data were evaluated for homogeneity and normality of errors (Bartlet and Shapiro-Wilk test) and, when significant, Box-Cox transformation was used (Box; Cox, 1964). After meeting the prerequisites, analysis of variance was performed to examine the effects of the isolated factors and their interaction ( $F$ test, $\alpha<0.05$ ). When there was a difference between treatments, multiple comparisons of means were used (Tukey's test, $\alpha<0.05$ ). The analyses were performed using Software ActionStat Pro $^{\circledR}$ (ActionStat v. 3.3.2). Graphs were generated using SigmaPlot ${ }^{\circledR}$ software (Systat Software v.10.0).

\section{RESULTS AND DISCUSSION}

The leaf water potential $\left(\Psi_{\mathrm{w}}\right)$ of sunflower plants differed separately due to the alleviating and substrate humidity (SH) factors (Figure 1a-b). Therefore, $\Psi_{\mathrm{w}}$ was higher in plants sprayed with potassium phosphite (KPhi), zinc sulfate (ZS) and the hydrogen sulfide donor $\left(\mathrm{H}_{2} \mathrm{~S}\right) \mathrm{NaHS}$ in both field capacities (FC) (Figure 1a). $\mathrm{H}_{2} \mathrm{~S}$ showed results similar to plants without product (WP) application, which showed lower values of $\Psi_{\mathrm{w}}$ (Figure 1a). The higher values of $\Psi_{\mathrm{W}}$ of sunflower plants were observed due to the spraying of the $\mathrm{H}_{2} \mathrm{~S}$ donor, and primarily KPhi and $\mathrm{ZS}$, which indicate a higher water content in the leaf tissues of the plants (Figure 1a-b). Batista et al. (2020), observed similar results in soybean plants under stress during 8 days of treatments, in which the application of these same alleviators promoted the maintenance of relative water content of plants under water deficit (WD) equal to well-watered (WW) plants. Although the $\Psi_{\mathrm{W}}$ was higher in the water deficit (WD) condition after spraying NaHS, KPhi, and ZS, the values were not statistically equal to those of the well-watered (WW) plants in the present study of sunflower plants (Figure 1b). There was also a mitigating effect regardless of substrate moisture level (Figure 1a). 


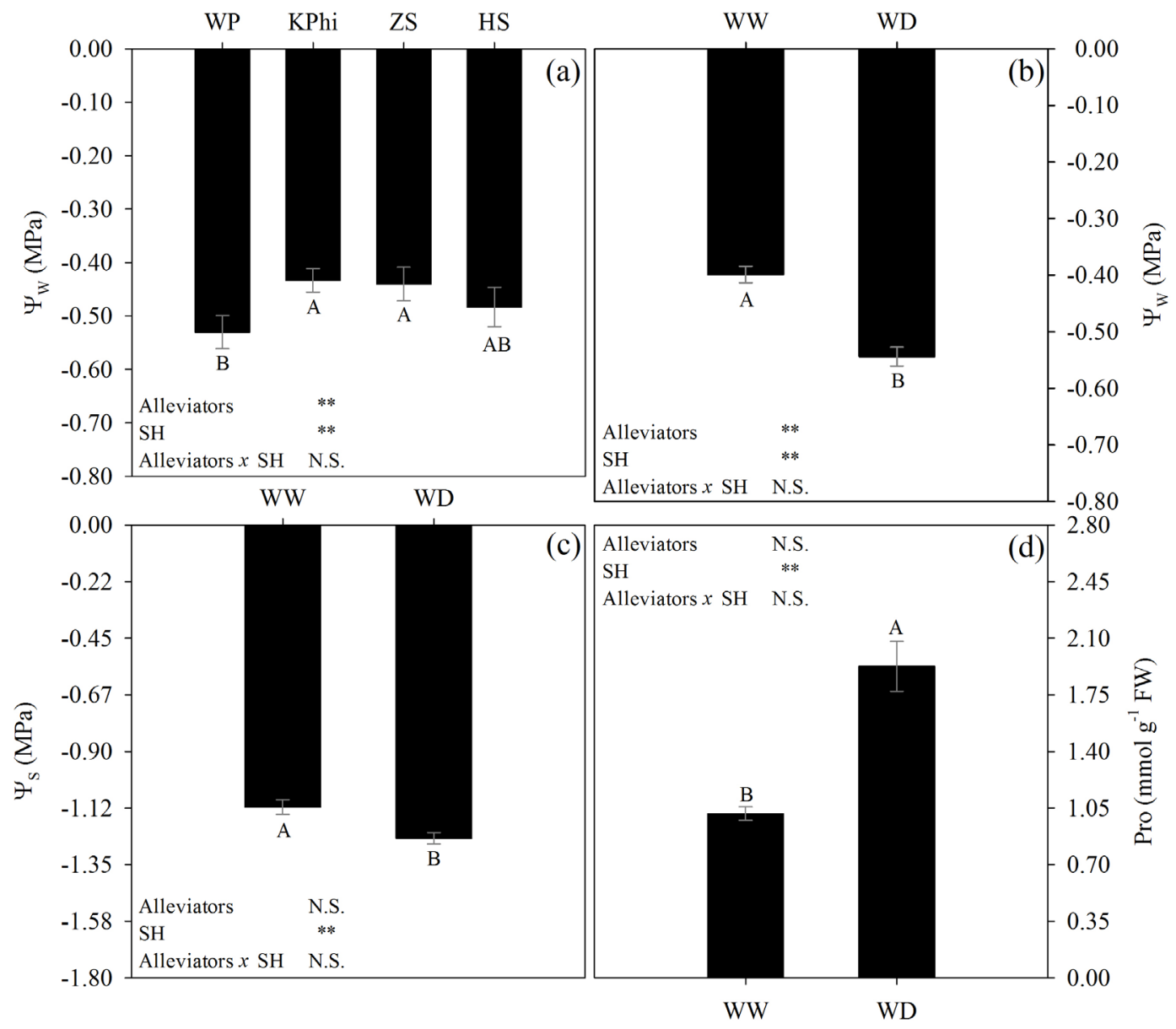

Figure 1: Water potential $\left[\Psi_{w^{\prime}}\left(a\right.\right.$ and b)], osmotic potential $\left[\Psi_{s^{\prime}}(c)\right]$ and proline concentration [Pro, (d)] of sunflower plants after 10 days of substrate humidity (SH) conditions of 100\% (well-watered, WW) and 30\% (water deficit, WD) of the field capacity (FC) combined with the spraying of the alleviators: potassium phosphite (KPhi), zinc sulfate (ZS), hydrogen sulfide (HS) donor NaHS, and without product (WP). Means followed by different capital letters between Alleviators $(n=10)$ or SH $(n=20)$ differ significantly from each other (Tukey's test $\alpha<0.01)$. Vertical bars indicate means \pm SE.

The proline (Pro) leaf concentration was higher in the WD condition and differed only as a function of FC (Figure 1d). The general strategy of plants for maintaining water in WD conditions is an osmotic adjustment, due to the accumulation of osmolytes (Chaumont; Tyerman, 2014; Nawaz et al., 2016; Silva et al., 2019). However, there was no differential osmotic adjustment due to the spraying of KPhi, NaHS, and ZS in the present study, which was observed in the results of osmotic potential $\left(\Psi_{\mathrm{S}}\right)$ (Figure 1c), with only an effect of the imposed water regimes. The Pro accumulation is one of the strategies used in collaboration with the osmo-protection, and it act as an antioxidant (Azmat; Moin, 2019). Unlike wheat and soybean plants under WD conditions, which showed an increase in Pro due to treatment with ZS (Ma et al., 2017; Batista et al., 2020), KPhi and $\mathrm{H}_{2} \mathrm{~S}$ (Batista et al., 2020).

The gas exchange parameters of sunflower plants differed only as a function of FC (Figure 2), and the photosynthetic rate $(A)$, stomatal conductance $\left(g_{s}\right)$, transpiration rate $(E)$, ratio between internal and external $\mathrm{CO}_{2}\left(C_{\mathrm{i}} / C_{\mathrm{a}}\right)$ and carboxylation efficiency $\left(A / C_{\mathrm{i}}\right)$ were lower in the WD condition (Figure 2a-d e Figure 2f). However, the water use efficiency ( $W U E$ ) was higher in the WD condition (Figure 2e). The lowest $A$ was primarily due to the restriction of stomatal opening, which was observed in soybean and Jatropha curcas plants under WD conditions (Silva et al., 2015; Castro et al., 2019). There was likely no damage to the biochemical stage of photosynthesis. One 


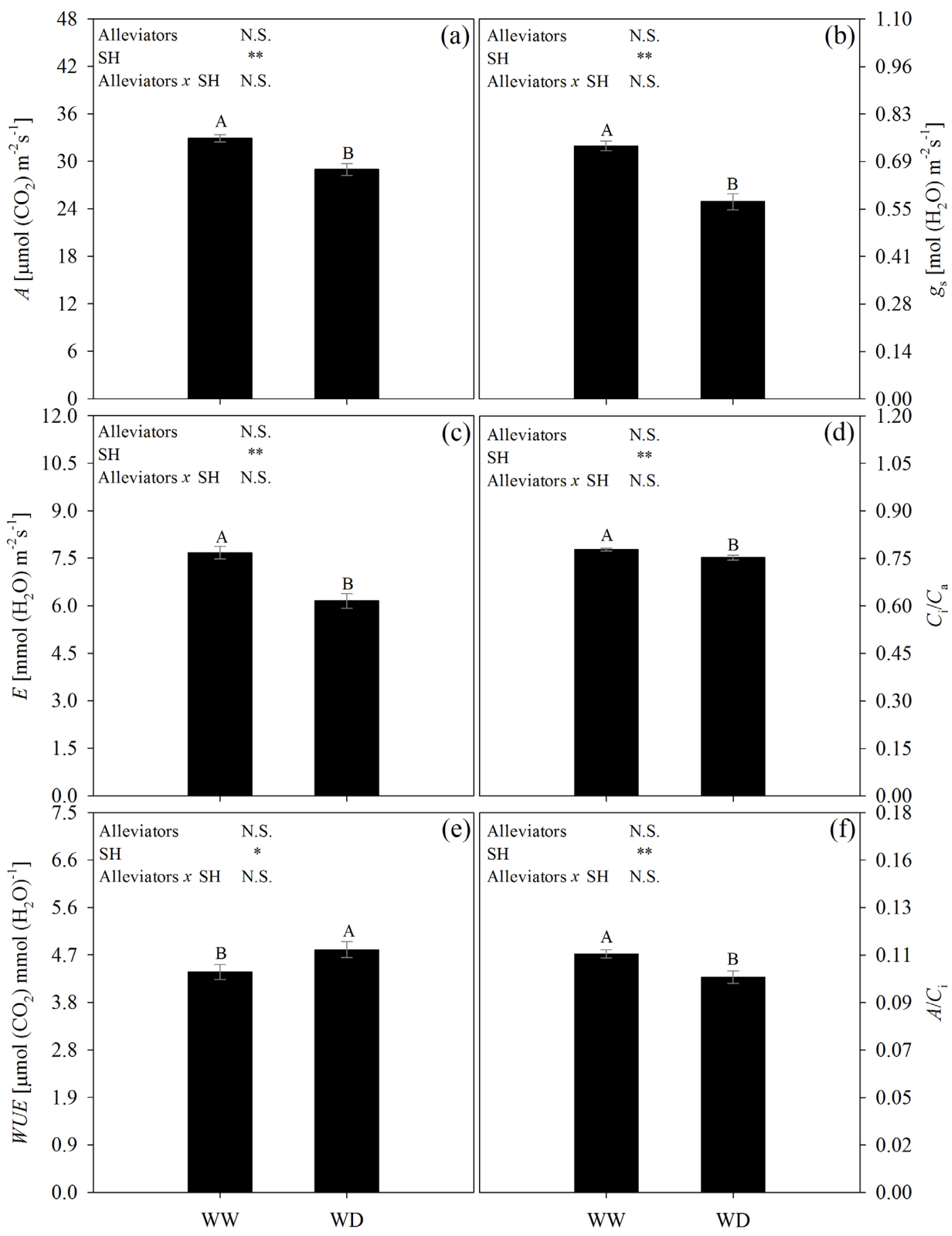

Figure 2: Photosynthetic rate $\left[A_{,}(a)\right]$, stomatal conductance $\left[g_{s^{\prime}}(b)\right]$, transpiration rate $\left[E_{,}(c)\right]$, relationship between internal and external $\mathrm{CO}_{2}$ concentration $\left[C / C_{a^{\prime}}\right.$ (d)], water use efficiency $\left[W U E_{,}(\mathrm{e})\right]$ and carboxylation efficiency of Rubisco $\left[A / C_{i,}(\mathrm{f})\right]$ of sunflower plants after 10 days in substrate humidity $(\mathrm{SH})$ conditions of $100 \%$ (well-watered, WW) and $30 \%$ (water deficit, WD) of the field capacity (FC) combined with the spraying of the alleviators: potassium phosphite (KPhi), zinc sulfate (ZS), hydrogen sulfide (HS) donor NaHS, and without product (WP). Means followed by different capital letters between SH $(n=20)$ differ significantly from each other using the Tukey's test $(a<0.05$ and $\mathrm{a}<0.01)$. Vertical bars indicate means $\pm \mathrm{SE}$. 
indication of damage to the Calvin-Benson cycle is the accumulation of $\mathrm{CO}_{2}$ in the substomatal chamber (Silva et al., 2015; Rivas et al., 2017), which cannot be verified in the ratio between the internal and external concentration of $\mathrm{CO}_{2}\left(C_{\mathrm{i}} / C_{\mathrm{a}}\right)$ (Figure $2 \mathrm{~d}$ ). Despite the $C_{\mathrm{i}} / C_{\mathrm{a}}$ ratio being $3.2 \%$ lower in the WD condition in the present study, a greater difference was expected compared to the WW condition. This result is due to the limitation of $g_{\mathrm{s}}$ affecting $A$ and $E$ more intensely than $C_{\mathrm{i}} / C_{\mathrm{a}}$ (Figure 2a-d), which corroborates the lower $A / C_{\mathrm{i}}$ observed in sunflowers (Figure 2f), which was unlike cocoa plants under WD conditions (Zanetti et al., 2016). Notably, the values of $A$ in WD conditions suggest that the imposed stress was not severe. These values were close to the values found by Vital et al. (2017) in sunflower plants, but in the control treatment.

The regulation of stomatal opening is a strategy to prevent plant dehydration via the loss of water in the atmosphere (Henry et al., 2019). There was a lower $E$ of sunflower plants due to the limitation of $g_{\mathrm{s}}$ as a function of WD. Therefore, the objective of the entire strategy of stomatal regulation under WD conditions is to increase the $W U E$ (Buezo et al., 2019). Furthermore, this increase in $W U E$, as expected, was verified in the sunflower plants in the present study (Figure 2e).

The potential quantum yield of photosystem II (PSII) $\left(F_{\mathrm{v}} / F_{\mathrm{M}}\right)$ did not differ between treatments (Figure $3 \mathrm{a}$ ). However, the effective quantum yield of PSII $\left(\Phi_{\mathrm{II}}\right)$ and the electron transport rate (ETR) differed as a function of FC and were lower in the WD condition (Figure $3 b$ e d). The nonphotochemical dissipation (NPQ), the excess energy relative to the PSII (EXC) and the ETR/A ratio were higher in the WD condition (Figure 3c e 3e-f). Therefore, the effects of WD on photosynthesis also occurred via a decrease in the efficiency of the photochemical step, which was observed in the effective quantum yield of the $\operatorname{PSII}\left(\Phi_{\mathrm{II}}\right)$ and the electron transport rate (ETR) (Figure $3 \mathrm{~b}$ and $3 \mathrm{~d})$. The ETR/A ratio was also indicative of the lower photosynthetic efficiency in the WD condition (Figure 3f) because sunflower plants demanded more electrons for each $\mathrm{CO}_{2}$ molecule assimilated. This effect was also seen in plants of Calotropis procera under the same stress condition (Rivas et al., 2017). Therefore, the $\mathrm{ETR} / A$ results corroborate the $A / C_{\mathrm{i}}$, parameter, indicate a disturbance in the assimilation of $\mathrm{CO}_{2}$ that was not only due to the stomatic restriction. Notably, $\mathrm{KPhi}, \mathrm{H}_{2} \mathrm{~S}$, and ZS were reported to alleviate the harmful effects of stress on photosynthetic machinery (Oyarburo et al., 2015; Ma et al., 2017), and act as inducers of the antioxidant defense system (Machinandiarena et al., 2018; Corpas, 2019), but no stress-alleviating effects of these substances were observed in the photosynthetic process of sunflower plants.
The increase in energy dissipation in NPQ is a strategy of tolerance to $\mathrm{WD}$ (Figure 3c). This response occurs due to the increased performance of the xanthophyll cycle, which is a strategy to prevent damage to the photosynthetic apparatus due to the excess of light energy (EXC) (Rivas et al., 2017; Głowacka et al., 2018). The regeneration of $\mathrm{ADP}$ and $\mathrm{NADP}^{+}$for the photochemical step is impaired with the lowest of the Calvin-Benson cycle, which generate a negative regulation of photosynthesis (Silva et al., 2015). Sunflower plant strategies were effective during WD stress to avoid the occurrence of photoinhibition. This success was verified in the stability of the $F_{\mathrm{V}} / F_{\mathrm{M}}$ ratio (Figure 3a) because the reduction of this variable is indicative of photoinhibition (Maxwell; Johnson, 2000), which was not observed in this study.

Among the chloroplast pigments, there was no difference between treatments for the content of chlorophyll $a(\mathrm{Chl} a)$ and carotenoids (Carot) (Table 1). The chlorophyll $b(\mathrm{Chl} b)$ content differed for factor FC, with lower values observed for plants under WD (Table 1). Corroborating with the $F_{\mathrm{V}} / F_{\mathrm{M}}$ results, there was no degradation of Chl $a$ content, which are part of the reaction center of the photosystems. However, WD reduced the content of Chl $b$ (Table 1), which plays an important role in the light harvesting complex (LHC) of photosystems (Nagao et al., 2020). This strategy decrease light absorption to avoiding photooxidative damage during stress conditions (Buezo et al., 2019).

There was an interaction between the Alleviating $x$ SH factors for the content of malondialdehyde (MDA) (Figure 4a) and activity of peroxidase (POX) (Figure $4 b$ ). The water deficit did not increase the MDA values in response to the application of the compounds, only without product. When compared between the substrate humidity per product, no difference was observed, except in plants sprayed with only water. The lower accumulation of MDA in sunflower plants due to the spraying of $\mathrm{NaHS}, \mathrm{KPhi}$, and ZS suppots the potential role of these substances in mitigating the oxidative stress caused by WD (Figure 4a), which was observed in soybean plants in development stage V4 and R1 (Batista et al., 2020). The content of MDA was statistically equivalent between the plants under WD and WW with the application of NaHS, KPhi, and ZS. This result indicates an important role of these substances in the antioxidant metabolism of sunflower plants because plants that received only water spray in the WD condition accumulated $46 \%$ more MDA than the WW condition. The MDA content observed in this work under optimal conditions (WW condition with spraying only water) was compatible with that observed by Vital et al. (2017), also under control conditions, which indicates that the plants in the WP treatment were under oxidative stress in the WD condition. 

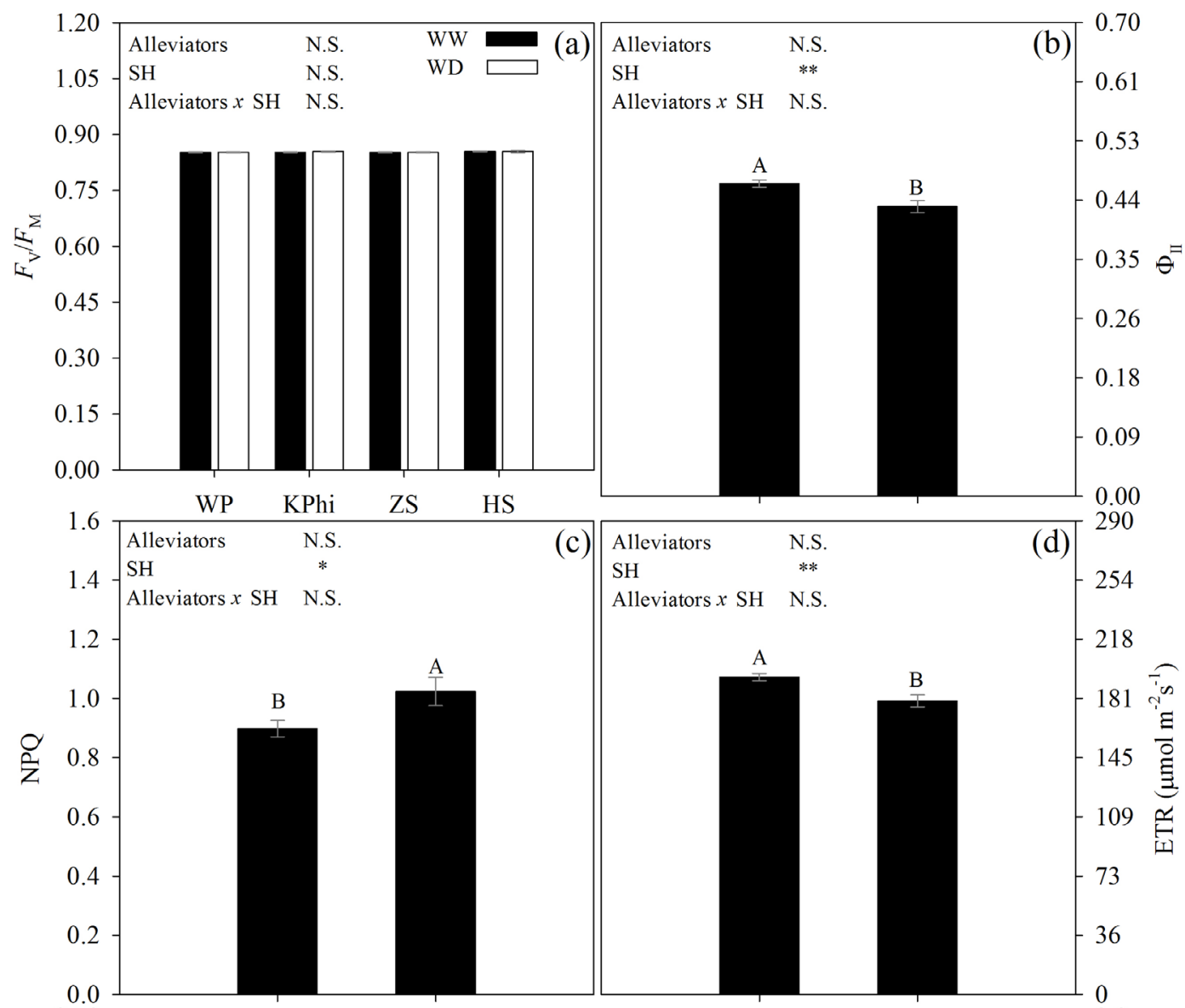

(c) Alleviators N.S.

0.00
290

$\begin{array}{ll}\text { Alleviators } & \text { N.S. } \\ \mathrm{SH} & * *\end{array}$

Alleviators $x$ SH N.S.

(d)

254
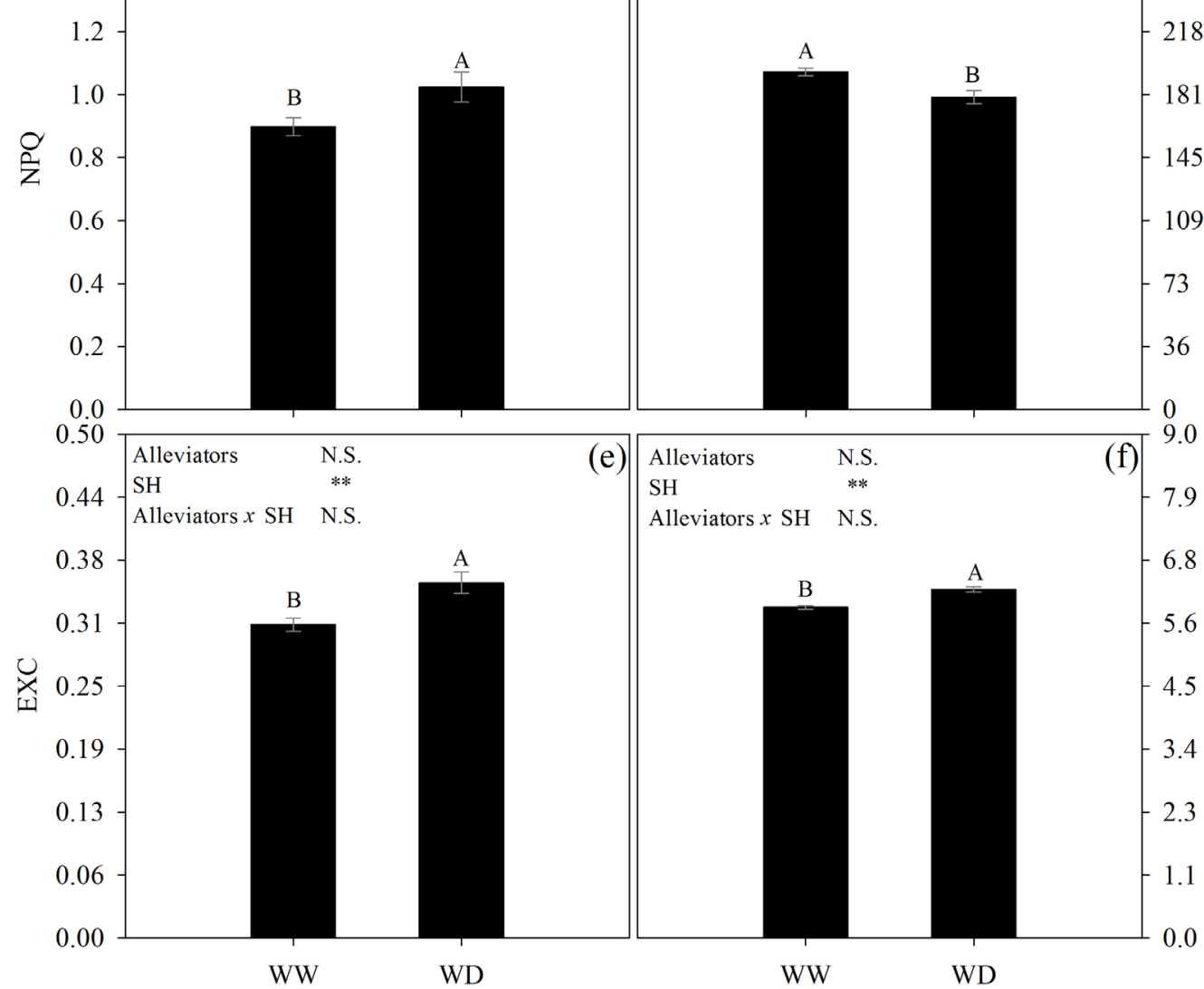

(e) Alleviators

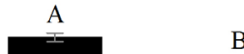

B

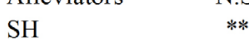

Alleviators $x$ SH N.S.

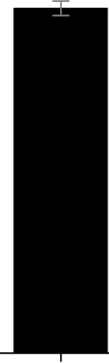

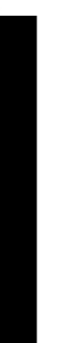

218

181 它

$-73$

$-36$

0

9.0

$-7.9$

$-6.8$

B

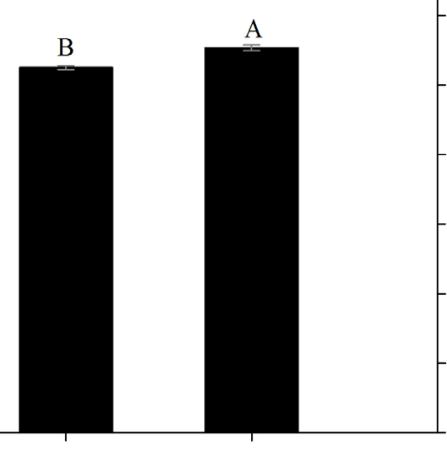

5.6

$4.5 \underset{\text { 空 }}{\stackrel{\Xi}{*}}$

3.4

2.3

1.1

WW

WD

Figure 3: Potential quantum yield $\left[F_{\mathcal{J}} F_{M^{\prime}}(\mathrm{a})\right]$ and effective $\left[\Phi_{\| \prime \prime}(\mathrm{b})\right]$ of the PSII, nonphotochemical dissipation [NPQ, (c)], electron transport rate [ETR, (d)], excess energy related to PSII [EXC, (e)], and the ratio ETR/A (f) of sunflower plants after 10 days under substrate humidity (SH) conditions of 100\% (well-watered, WW) and 30\% (water deficit, WD) of the field capacity (FC) combined with the spraying of alleviators: potassium phosphite (KPhi), zinc sulfate (ZS), hydrogen sulfide (HS) donor NaHS, and without product (WP). Means followed by different capital letters between SH $(n=20)$ differed significantly from each other using the Tukey's test $(a<0.05)$. Vertical bars indicate means $\pm \mathrm{SE}$. 
Table 1: Chlorophyll $a(\mathrm{Chl} a)$, chlorophyll $b(\mathrm{Chl} b)$ and carotenoids (Carot) content of sunflower plants after 10 days in substrate humidity (SH) conditions of 100\% (well-watered, WW) and 30\% (water deficit, WD) of the field capacity (FC) combined with the spraying of alleviators: potassium phosphite (KPhi), zinc sulfate (ZS), hydrogen sulfide (HS) donor NaHS, and without product (WP).

\begin{tabular}{cccc}
\hline & Chl $a$ & Chl $b$ & Carot \\
\cline { 2 - 4 } & \multicolumn{3}{c}{ WW $\left.\mathrm{cm}^{-2} \mathrm{FW}\right]$} \\
\hline WP & $38.66 \pm 2.77$ & $14.47 \pm 0.32$ & \\
KPhi & $38.75 \pm 1.68$ & $14.85 \pm 1.54$ & $7.57 \pm 0.52$ \\
ZS & $40.42 \pm 2.43$ & $15.20 \pm 0.90$ & $7.42 \pm 0.34$ \\
HS & $45.07 \pm 2.26$ & $15.92 \pm 1.21$ & $7.92 \pm 0.31$ \\
Mean & $40.73 \pm 1.22$ & $15.11 \pm 0.52 \mathrm{~A}$ & $8.79 \pm 0.52$ \\
\hline WP & WD - 30\% of FC & $7.93 \pm 0.23$ \\
KPhi & $40.04 \pm 1.82$ & $14.06 \pm 0.48$ \\
ZS & $42.33 \pm 2.03$ & $14.90 \pm 1.13$ & $7.59 \pm 0.47$ \\
HS & $36.88 \pm 4.18$ & $13.42 \pm 0.92$ & $8.08 \pm 0.36$ \\
\hline Mean & $40.54 \pm 2.64$ & $13.75 \pm 0.58$ & $7.58 \pm 0.81$ \\
\hline C.V. (\%) & $39.95 \pm 1.37$ & $14.03 \pm 0.40 B$ & $7.87 \pm 0.46$ \\
\hline Alleviators & 13.38 & 9.59 & $7.78 \pm 0.26$ \\
SH & N.S. & N.S. & 13.78 \\
Alleviators $x$ SH & N.S. & N.S. & N.S. \\
\hline N.S. & N.S. & N.S.
\end{tabular}

Means followed by different capital letters between SH $(n=20)$ differ significantly from each other using Tukey's test $(a<0.05)$. Vertical bars indicate means $\pm \mathrm{SE}$.

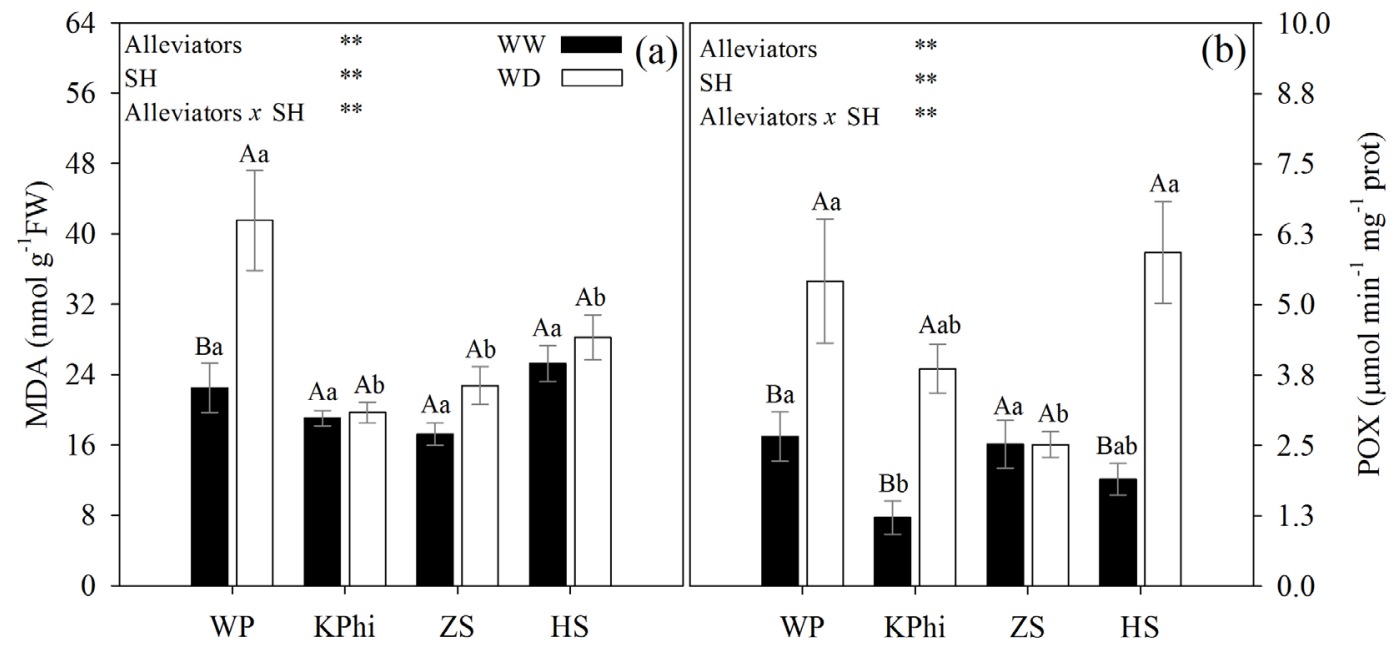

Figure 4: Malonaldehyde content [MDA, (a)] and peroxidase activity [POX, (b)] of sunflower plants after 10 days in substrate humidity (SH) conditions of 100\% (well-watered, WW) and $30 \%$ (water deficit, WD) of the field capacity (FC) combined with the spraying of alleviators: potassium phosphite (KPhi), zinc sulfate (ZS), hydrogen sulfide (HS) donor $\mathrm{NaHS}$, and without product (WP). Means followed by different capital letters between SH and lower letters between Alleviators differed significantly from each other using Tukey's test $(a<0.01)$. Vertical bars indicate means $\pm S E$. 
POX activity was higher in plants under water deficit than in well-watered plants in the absence of alleviators and after the spraying of KPhi and NaHS. Plants treated with ZS did not differ between water availability conditions, which indicates that other antioxidant enzymes may have acted because the MDA content did not increase in the WD condition. One possible enzyme with increased activity is superoxide dismutase, which use zinc as a metal cofactor (Marreiro et al., 2017; Batista et al., 2020). The spraying of KPhi induced less POX activity in well-watered plants than WP and ZS. Under water deficit, greater POX activities occurred in the WP and NaHS treatments. The induction in POX activity may have contributed to plant protection against damage to cell membranes (Figure 4b). The role of $\mathrm{H}_{2} \mathrm{~S}$ in increasing the antioxidant metabolism of plants under WD conditions was reported (Corpas, 2019). This increase was observed in wheat and soybean plants, in which the application of NaHS promoted a reduction in the content of MDA and $\mathrm{H}_{2} \mathrm{O}_{2}$ due to the increased activity of antioxidant enzymes, including peroxidase (Ma et al., 2016; Zhang et al., 2010). The application of NaHS increased the biosynthesis of abscisic acid and promoted stomatal closure in wheat plants (Ma et al., 2016). KPhi also acted in the potentiation of the sunflower antioxidant system in the WD condition via increasing POX activity, which corroborates observations in potato plants (Oyarburo et al., 2015; Machinandiarena et al., 2018).

WD stress decreased the growth of sunflower plants based on the reduction in biometric characteristics at the end of the stress period (Figure 5). Among the biometric variables, plant height, stem diameter, leaf dry matter, and stem dry matter differed as a function of FC, with lower values detected in the WD condition (Figure 5c-f). However, the number of leaves and the nodes of sunflower plants did not differ as function of the treatments (Figure 5a-b). There was no alleviation of the WD condition in reducing the biometric characteristics of plants with the spraying of NaHS, KPhi, and ZS. The decrease in growth primarily occurred due to the restriction of $\mathrm{CO}_{2}$ assimilation and reduction in the accumulation of biomass, which was reported in other plants with high oil production potential (Moura et al., 2018).

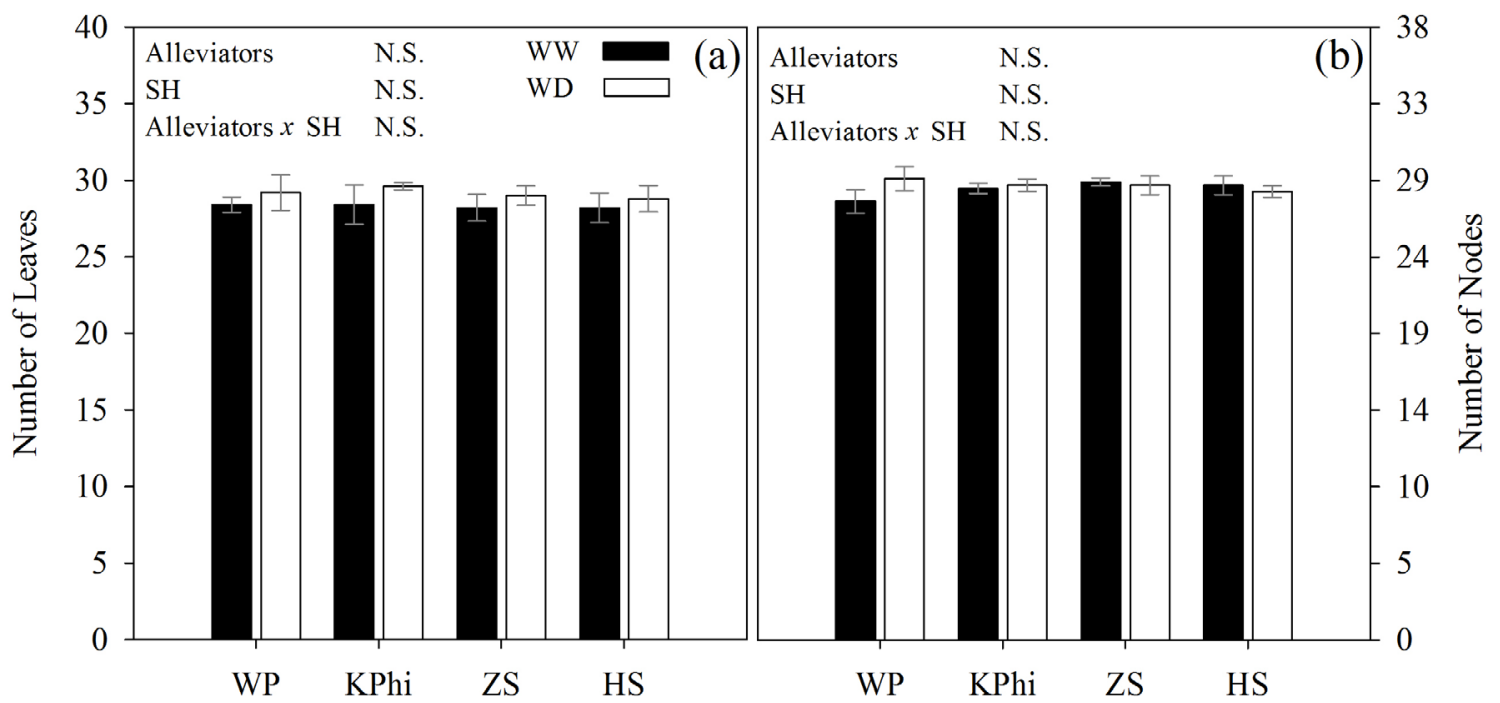

Figure 5: Number of leaves (a), number of nodes (b), plant height (c), stem diameter (d), leaf dry matter [LDM, (e)] and stem dry matter [SDM, (f)] of sunflower plants after 10 days in substrate humidity (SH) conditions of $100 \%$ (well-watered, WW) and 30\% (water deficit, WD) of the field capacity (FC) combined with the spraying of alleviators: potassium phosphite (KPhi), zinc sulfate (ZS), hydrogen sulfide (HS) donor NaHS, and without product (WP). Means followed by different capital letters between $\mathrm{SH}(\mathrm{n}=20)$ differed significantly from each other using Tukey's test $(a<0.01)$. Vertical bars indicate means \pm SE.

Continue... 


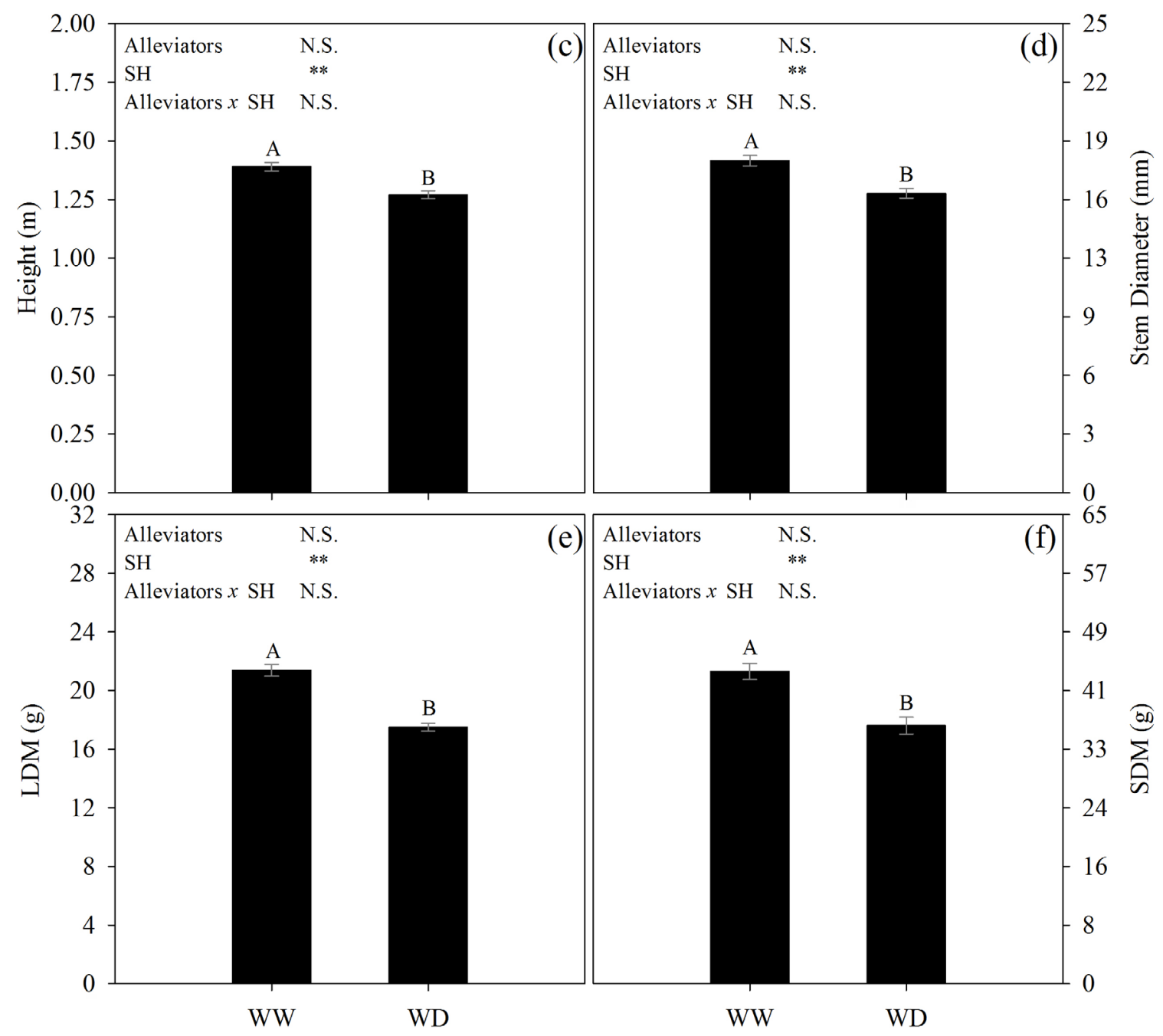

Figure 5: Continuation.

\section{CONCLUSIONS}

The spraying of potassium phosphite, zinc sulfate, and the hydrogen sulfide donor sodium hydrosulfide on sunflower plants mitigated the effects of drought stress by acting specifically in physiological processes related to antioxidant responses and the maintenance of water in leaf tissues. However, there was no alleviation of water deficit for photosynthetic processes. These results indicate the potential of these substances to mitigate water deficit in sunflower crop and the importance of carrying out field experiments.

\section{ACKNOWLEDGMENTS}

The authors are grateful to the $\mathrm{CNPq}$ (Conselho Nacional de Desenvolvimento Científico e Tecnológico,
Brazil), CAPES (Coordenação de Aperfeiçoamento de Pessoal de Nível Superior, Brazil), FAPEG (Fundação de Amparo à Pesquisa do Estado de Goiás), Instituto Federal Goiano - Campus Rio Verde and the PPGCA (Programa de Pós-Graduação em Ciências Agrárias - Agronomia).

\section{REFERENCES}

AZMAT, R.; MOIN, S. The remediation of drought stress under VAM inoculation through proline chemical transformation action. Journal of Photochemistry and Photobiology B: Biology, 193:155-161, 2019.

BATES, L. S.; WALDREN, R. P.; TEARE, I. D. Rapid determination of free proline for water-stress studies. Plant and Soil, 39(1):205-207, 1973. 
BATISTA, P. F. et al. Biochemical and physiological impacts of zinc sulphate, potassium phosphite and hydrogen sulphide in mitigating stress conditions in soybean. Physiologia Plantarum, 168(2):456-472, 2020.

BATISTA, P. F. et al. Nitric oxide mitigates the effect of water deficit in Crambe abyssinica. Plant Physiology and Biochemistry, 129:310-322, 2018.

BILGER, W.; SCHREIBER, U.; BOCK, M. Determination of the quantum efficiency of photosystem II and of nonphotochemical quenching of chlorophyll fluorescence in the field. Oecologia, 102(4):425-432, 1995.

BOX, G. E.; COX, D. R. An analysis of transformations. Journal of the Royal Statistical Society: Series B Statistical Methodological, 26(2):211-243, 1964.

BRADFORD, M. M. A rapid and sensitive method for the quantitation of microgram quantities of protein utilizing the principle of protein-dye binding. Analytical Biochemistry, 72(1-2):248-254, 1976.

BUEZO, J. et al. Drought tolerance response of high-yielding soybean varieties to mild drought: Physiological and photochemical adjustments. Physiologia Plantarum, 166(1):88-104, 2019.

CASTRO, C.; LEITE, R. D. C. Main aspects of sunflower production in Brazil Cesar. Oilseeds \& Fats Crops and Lipids, 25(1):1-11, 2018.

CASTRO, J. N. et al. Physiological tolerance to drought under high temperature in soybean cultivars. Australian Journal of Crop Science, 13(6):976-987, 2019.

CHANCE, B.; MAEHLEY, A. C. Assay of catalases and peroxidases. Methods in Enzymology, 2:764-775, 1955.

CHAUMONT, F.; TYERMAN, S. D. Aquaporins: Highly regulated channels controlling plant water relations. Plant Physiology, 164(4):1600-1618, 2014.

CORPAS, F. J. Hydrogen sulfide: A new warrior against abiotic stress. Trends in Plant Science, 24(11):983-988, 2019.

COSTA, A. C. et al. The effect of irradiance and water restriction on photosynthesis in young jatobá-do-cerrado (Hymenaea stigonocarpa) plants. Photosynthetica, 53(1):118-127, 2015.

DAI, A.; ZHAO, T.; CHEN, J. Climate change and drought: A precipitation and evaporation perspective. Current Climate Change Reports, 4(3):301-312, 2018.

DINIS, L. T. et al. Kaolin-based, foliar reflective film protects photosystem II structure and function in grapevine leaves exposed to heat and high solar radiation. Photosynthetica, 54(1):47-55, 2016.

FOOD AND AGRICULTURE ORGANIZATION OF THE UNITED NATIONS - FAO. FAOSTAT, Production Quantity: Sunflower. 2019. Available in: <http://www.fao.org/faostat/ en/\#data/QC>. Access in: March, 20, 2019.

GARCÍA-MATA, C.; LAMATTINA, L. Hydrogen sulphide, a novel gasotransmitter involved in guard cell signalling. New Phytologist, 188(4):977-984, 2010.

GENTY, B.; BRIANTAIS, J. M.; BAKER, N. R. The relationship between the quantum yield of photosynthetic electron transport and quenching of chlorophyll fluorescence. Biochimica et Biophysica Acta - General Subjects, 990(1):87-92, 1989.

GŁOWACKA, K. et al. Photosystem II Subunit S overexpression increases the efficiency of water use in a field-grown crop. Nature Communications, 9(1):1-9, 2018.

GÓMEZ-MERINO, F. C.; TREJO-TÉLLEZ, L. I. Biostimulant activity of phosphite in horticulture. Scientia Horticulturae, 196:82-90, 2015.

HEATH, R. L.; PACKER, L. Photoperoxidation in isolated chloroplasts. I. Kinetics and stoichiometry of fatty acid peroxidation. Archives of Biochemistry and Biophysics, 125(1):189-198, 1968.

HENRY, C. et al. A stomatal safety-efficiency trade-off constrains responses to leaf dehydration. Nature Communications, 10(1):1-9, 2019.

KAHLAOUI, B. et al. Physiological and biochemical responses to the exogenous application of proline of tomato plants irrigated with saline water. Journal of the Saudi Society of Agricultural Sciences, 17(1):17-23, 2018.

KAR, M.; MISHRA, D. Catalase, peroxidase, and polyphenoloxidase activities during rice leaf senescence. Plant Physiology, 57(2):315-319, 1976.

LAISK, A.; LORETO, F. Determining photosynthetic parameters from leaf $\mathrm{CO}_{2}$ exchange and chlorophyll fluorescence1: Ribulose-1,5-bisphosphate carboxylase/oxygenase specificity factor, dark respiration in the light, excitation distribution between photosystems, alternative electron transport rate, and mesophyll diffusion resistance. Plant Physiology, 110(3):903-912, 1996.

$\mathrm{LI}$, J. et al. Influence of drought stress on photosynthetic characteristics and protective enzymes of potato at seedling stage. Journal of the Saudi Society of Agricultural Sciences, 16(1):82-88, 2017. 
MA, D. et al. Alleviation of drought stress by hydrogen sulfide is partially related to the abscisic acid signaling pathway in wheat. PLoS ONE, 11(9):1-16, 2016.

MA, D. et al. Physiological responses and yield of wheat plants in zinc-mediated alleviation of drought stress. Frontiers in Plant Science, 8:1-12, 2017.

MACHINANDIARENA, M. F. et al. The reinforcement of potato cell wall as part of the phosphite-induced tolerance to UV-B radiation. Biologia Plantarum, 62(2):388-394, 2018.

MARREIRO, D. N. et al. Zinc andoxidative stress: Current mechanisms. Antioxidants, 6(2):24-32, 2017.

MAXWELL, K.; JOHNSON, G. N. Chlorophyll fluorescence: A practical guide. Journal of Experimental Botany 51(345):659-668, 2000.

MILADINOVIĆ, D. et al. Sunflower and climate change: Possibilities of adaptation through breeding and genomic selection. In: CHITTARANJAN, K. Genomic Designing of Climate-Smart Oilseed Crops. Springer International Publishing, p. 173-238, 2019.

MONJEZI, F.; VAZIN, F.; HASSANZADEHDELOUEI, M. Effects of iron and zinc spray on yield and yield components of wheat (Triticum Aestivum L.) in drought stress. Cercetari Agronomice in Moldova, 46(1):23-32, 2013.

MORA, C. et al. Global risk of deadly heat. Nature Climate Change, 7(7):501-506, 2017.

MOURA, L. M. F. Drought tolerance in potential oilseed plants for biofuel production. Australian Journal of Crop Science, 12(2):289-298, 2018.

NAGAO, R. et al. Structural basis for assembly and function of a diatom photosystem I-light-harvesting supercomplex. Nature Communications, 11(1):1-12 2020.

NAWAZ, M. et al. Proteomic analysis of soybean root including hypocotyl during recovery from drought stress. Article in Journal of proteomics, 144:39-50, 2016.

OYARBURO, N. S. et al. Potassium phosphite increases tolerance to UV-B in potato. Plant Physiology and Biochemistry, 88:1-8, 2015.

PASK, A. J. D. et al. Physiological breeding II: A field guide to wheat phenotyping. Cimmyt, 2012. 134p.

RIBEIRO, I. O. et al. Biomass burning and carbon monoxide patterns in Brazil during the extreme drought years of 2005, 2010, and 2015. Environmental Pollution, 243:10081014, 2018.
RIVAS, R. et al. Photosynthetic limitation and mechanisms of photoprotection under drought and recovery of Calotropis procera, an evergreen C3 from arid regions. Plant Physiology and Biochemistry, 118:589-599, 2017.

SABIR, A.; SARI, G. Zinc pulverization alleviates the adverse effect of water deficit on plant growth, yield and nutrient acquisition in grapevines (Vitis vinifera L.). Scientia Horticulturae, 244:61-67, 2019.

SILVA, E. N. et al. Photoprotective function of energy dissipation by thermal processes and photorespiratory mechanisms in Jatropha curcas plants during different intensities of drought and after recovery. Environmental and Experimental Botany, 110:36-45, 2015.

SILVA, D. C. et al. Silicon foliar application attenuates the effects of water suppression on cowpea cultivars. Ciência e Agrotecnologia, 43:e023019, 2019.

SINGH, V. P.; TRIPATHI, D. K.; FOTOPOULOS, V. Hydrogen sulfide and nitric oxide signal integration and plant development under stressed/non-stressed conditions. Physiologia Plantarum, 168(2):239-240, 2020.

SOARES, M. M. et al. Effects of Competition and water deficiency on sunflower and weed growth. Revista Caatinga, 32(2):318-328, 2019.

TARIQ, A. et al. Phosphorous fertilization alleviates drought effects on Alnus cremastogyne by regulating its antioxidant and osmotic potential. Scientific Reports, 8(1):1-11, 2018.

VAN OOSTEN, M. J. et al. The role of biostimulants and bioeffectors as alleviators of abiotic stress in crop plants. Chemical and Biological Technologies in Agriculture, 4(5):1-12, 2017.

VITAL, R. G. Physiological changes and in the carbohydrate content of sunflower plants submitted to sub-doses of glyphosate and trinexapac-ethyl. Bragantia, 76(1):33-44, 2017.

WELLBURN, R. W. The spectral determination of chlorophylls $a$ and $b$, as well as total carotenoids, using various solvents with spectrophotometers of different resolution. Journal of Plant Physiology, 144(3):307-313, 1994.

ZANETTI, L. V. et al. Leaf application of silicon in young cacao plants subjected to water deficit. Pesquisa Agropecuária Brasileira, 51(3):215-223, 2016.

ZAFAR, S. et al. Effect of zinc and sulfur foliar applications on physiological characteristics of sunflower (Helianthus annuus L.) under water deficit stress. International Journal of Biosciences, 5(12):87-96, 2014. 
ZHANG, H. et al. Hydrogen sulfide protects soybean seedlings against drought-induced oxidative stress. Acta Physiologiae Plantarum, 32(5):849-857, 2010.
ZHOU, L. et al. Exogenous abscisic acid significantly affects proteome in tea plant (Camellia sinensis) exposed to drought stress. Horticulture Research, 1:1-9, 2014. 